\title{
Ratib al-Attas Menurut Perspektif al-Quran dan Hadis
}

\author{
Mohd Azman Mohsin, Md Hamzaimi Azrol Md Baharudin*, Nasri Abdullah, Siti Salwa Md. Sawari, Othman Napiah, Sulaiman Shakib \\ Mohd. Noor, Kamarul Azmi Jasmi \\ Fakulti Tamadun Islam, Universiti Teknologi Malaysia,81310 UTM Johor Bahru, Johor, Malaysia \\ *Corresponding author: azrol1231@gmail.com
}

\begin{abstract}
This article aims to evaluate the source of 17 dhikr in Ratib al-Attas based on Quran, Hadith and scholar views on the meaning and purpose of dhikr. Applications Ratib al-Attas ceremony was conducted over 90 years ago in the state of Johor. In addition, the application Ratib al-Attas assessment and justification is given from the perspective of Islamic practices. The method used is by clarifying the position of remembrance 17 Ratib al-Attas more reliable by practitioners; avoid confusion and misunderstanding of the doctrine of Ratib al-Attas. The results showed that all 17 dhikr Ratib al-Attas and the practice carried out are consistent with the arguments of al-Quran and Hadith. Based on this finding several suggestions is made to encourage the expend development of dhikr al-Attas Ratib practice among the Muslim community in Malaysia.
\end{abstract}

Keywords: Remembrance; Ratib al-Attas; Quran and Hadith

\begin{abstract}
Abstrak
Artikel ini bertujuan untuk membuat penilaian terhadap sumber zikir 17 dalam Ratib al-Attas berdasarkan sumber al-Quran, hadis dan pandangan ulama terhadap maksud dan tujuan zikir tersebut. Aplikasi majlis Ratib al-Attas ini telah dijalankan lebih 90 tahun dahulu di Negeri Johor. Selain itu, kaedah aplikasi Ratib al-Attas ini diberikan penilaian dan justifikasi dari perspektif amalan Islam. Kaedah kajian yang digunakan ialah dengan menjelaskan kedudukan zikir 17 Ratib al-Attas untuk lebih diyakini oleh para pengamal dan menghindarkan kekeliruan dan salah faham terhadap doktrin Ratib al-Attas. Dapatan menunjukkan bahawa kesemua 17 zikir Ratib al-Attas dan bentuk pengamalan yang dijalankan adalah sangat bertepatan dengan dalil-dalil al-Quran dan Hadis. Berdasarkan dapatan ini beberapa cadangan dikemukakan bagi menggalakkan pengamalan zikir Ratib al-Attas ini untuk dikembang luaskan dalam kalangan masyarakat Islam di Malaysia.
\end{abstract}

Kata Kunci: Zikir; Ratib al-Attas; al-Quran dan Hadis

(C) 2016 Penerbit UTM Press. All rights reserved

\subsection{PENGENALAN}

Ilmu tasawuf adalah satu satu cabang dan displin ilmu dalam Islam. Ia memiliki banyak nama atau gelaran seperti ilmu hati (ilmu qalb atau wijdan), ilmu batin, ilmu terus dari Allah (laduni), ilmu rahsia (asrar), ilmu hakikat, ilmu rasa rohani (zauqi), ilmu ihsan, ilmu alTazkiyah, al-Suluk, al-Kasyaf dan ilmu ikhlas. (Mahmod Saedon, 1987; Abdul Fatah Haron, 2006; Zulkifli al-Bakri, 2009). Menurut Sayid Sabiq, tasawuf adalah berlian Islam, manakala menurut Prof. Dr. Hamka, tasawuf merupakan wujud praktik dari rukun Ihsan. Tahap ke tiga dalam disiplin dasar agama iaitu Ihsan selepas Islam, Iman. Menepati maqam ihsan sebagaimana hadis yang ke 2 daripada susunan alImam an-Nawawi r.a (Abdul Hafiz Faraghli, 2002).

Doktrin ilmu tasawuf, tarekat, prinsip dan pengamalannya telah wujud sejak zaman Baginda Rasulullah s.a.w, para sahabat, tabien dan salafus soleh, walaupun istilah tasawuf tersebut belum dikenali dan digunakan secara khusus. Ini bersesuaian dengan penggunaan perkataan tarekat atau tarek yang terdapat di dalam al-Quran dengan makna "jalan" atau "sabil" atau "sirat" (Jahid,1994).

Menurut al-Habib Abdullah al-Haddad bahawa tarekat dalam ilmu tasawuf telah mengambil jalan para salafus soleh yang antaranya terdiri dari wasilah ahli bait Rasulullah s.a.w jejak demi jejak, langkah demi langkah kembara menuju Allah. Perjalanan (tarek dan sabil), kembara dan perjuangan (mujahadah) bagi menghimpunkan segala bentuk kebenaran yang dinikmati secara hakiki dalam kehidupan. Kebenaran yang satu iaitu jalan yang lurus (siratal mustaqim) sebagaimana firman Allah S.W.T dalam Surah al-An'am pada ayat 153 yang bermaksud:

"Dan bahawa sesungguhnya inilah jalanKu (agama Islam) yang betul lurus, maka hendaklah kamu menurutnya; dan janganlah kamu menurut menurut jalan-jalan (yang lain dari Islam), kerana jalan-jalan (yang lain itu) mencerai-beraikan kamu dari jalan Allah, dengan yang demikian itulah Allah perintahkan kamu, supaya kamu bertaqwa".

Menurut al-Imam Abi Muhammad al-Bagahwi, 1995 hal. 468) menjelaskan bahawa inilah yang diwasiat dan diperintahkan Allah S.W.T agar mengikuti sirati, jalanKu dan agamaKu yang lurus, tepat dan mantap iaitu agama Islam yang memiliki objektif yang jelas, jalan yang lurus dan agama keredhaan Allah S.W.T maka ikutilah secara keseluruhannya. 
Ilmu tasawuf yang terkandung di dalamnya tarekat, zikrullah, guru dan murid sering mendapat perhatian dari para sarjana Islam untuk meneliti dan mengkaji kedudukan ilmu tersebut samada bertepatan dengan kehendak Islam. Hal ini telah menyebabkan berlakunya perbezaan pandangan dikalangan para ulama. Isu penyelewengan para guru tarekat dan zikir yang diamalkan adalah antara punca ilmu tasawuf dipandang negatif dan ditolak oleh sebahagian ulama. Bermula pada kurun yang ke 8H seperti Ibnu Taimiyah (w.728H), Ibnu Qayyim (w.751H), al-Khatib al-Sharbini (w.977H) dan ulama mutakhir dalam majlis fatwa Lajnah al-Daimah li al-Buhuth al-Ilmiah wa al-Ifta' yang membid'ahkan amalan berzikir dengan zikir ism al-zat, bahkan mengaplikasikannya secara berjamaah di masjid atau di mana sahaja adalah satu kemungkaran kerana tiada dalil bersumberkan al-Quran dan sunnah. Pendapat mereka telah ditentang oleh para ulama tasawuf dan tarekat yang menjelaskan tentang dalil keharusan zikrullah dengan lafaz tertentu secara bersendirian mahupun berjamaah dengan suara yang kuat dan di pimpin oleh para naqib dalam tarekat (Syed Omar, 2010; Muhammad, 2013; Al-Kurdī, 2004).

Antara tarekat yang masyhur dalam dunia Islam ialah Tarekat Alawiyah diasaskan oleh Saidina al-Faqih Muqadam Muhammad bin Ali Ba Alawi generasi ke 11 hingga kepada Rasulullah SAW (Al-'Ațtās, S. A., t.th.; Al-Šiblī, 1982). Tarekat Alawiyah ini telah berkembang seterusnya menyumbang jasa yang tidak terhingga kepada dunia Islam khususnya di Nusantara kerana mengislamkan orang melayu sejak kedatangan Islam 1,400 tahun yang lalu melalui dakwah dan perdagangan terutama wali Sembilan di Tanah Jawa, Indonesia yang bernasab hingga kepada Rasulullah SAW (Al-Jufri, 2013). Mereka menjadi Sultan setelah mengahwini puteri raja, menjadi ulama, mufti, dan wali Allah yang berjuang tanpa rasa takut dan duka atas segala tribulasi yang dihadapi ternyata mereka mendapat pertolongan Allah.(Fauzi, 2013; Al-Haddād, 1991; Azra, 2008).

Pengasas Ratib al-Attas (Sahib) Ratib al-Attas iaitu Habib Umar bin Abdul Rahman al-'Attas (1.992H-w.1072H) maqamnya di Kota Huraidah, Hadramaut, Yaman (Al-'Atțās, S. M. N. A., 1977; Al- 'Atțās, H. H. A., t.th.; Al-'Atțās, H. A. A. H., 1968). Nasab beliau sampai kepada Rasulullah s.a.w. Fatimah al-Zahra binti Rasulullah SAW dan suami Saidina Ali bin Abu Talib. Penduduk Kota Huraidah, Hadramaut, Yaman suatu ketika menghadapi isu ekonomi kerana kota itu menghadapi kemarau, tersebar wabak penyakit dan isu ajaran sesat di kalangan penduduk, lalu penduduk Kota Huraidhah meminta beliau menyusun satu amalan zikir atau ratib yang dapat diamalkan oleh penduduk secara berjamaah bagi memohon Allah mengembalikan kesejahteraan dan keselamatan (wellness) penduduk dari isu akidah dan ekonomi para penduduk Kota Huraidhah (Al- 'Ațtās, H. A. H., 2007).

\subsection{LATARBELAKANG APLIKASI RĀTIB AL-ATTĀS}

Amalan ini telah menjadi amalan yang berterusan diamalkan oleh para penduduk Kota Huraidah, Yaman secara berjamaah samada di Masjid, Madrasah serta rumah-rumah di sana sehingga hari ini. Amalan berjamaah selepas solat isyak, manakala selepas maghrib pada bulan Ramadhan (Al- 'Aț̣ās, A.-Ḥ. S. M., 2014; Al-Haddād, a.-H. S. A. B., 2013). Amalan tarekat ini terus berkembang sehingga ke Burma, Indonesia, Malaysia, Singapura dan Brunei Darul Salam (Al-'Aț̣ās, S. M., 2008). Di Negeri Johor Darul Takzim, Malaysia amalan ini berkembang sejak 1922 berdasarkan doktrin Ratib al-Attas cetakan Wakaf Madrasah al-Attas al-Arabiyah, Johor Bahru, Johor yang dibangunkan oleh Habib Hasan bin Ahmad al-Attas, pengasas Madrasah al-Attas, Johor Bahru dan Pekan, Pahang (w.1932). Madrasah alAttas al-Arabiyah yang dibina pada 1913 hingga kini telah berjaya melahirkan ramai pembesar, ulama dan cendiakawan (Al-Muarī, M., Mohd.Azman 2006; Al-'Ațtās, S. A., 2013). Kebanyakan Mufti di Negeri Johor suatu masa dahulu adalah di kalangan keturunan Rasulullah seperti Habib Salim bin Ahmad al-Attas, Habib Abdul Qadir bin Mohsin al-Attas, Habib Alwi bin Tahir al-Haddad, Habib Alwi bin Abdullah al-Haddad (Fauzi, N. W., 2012). Manakala di Singapura doktrin Ratib al-Attas yang dicetak pada tahun 1952 oleh Habib Muhammad bin Salim al-Attas, pengasas Masjid BaAlawi, Singapura (Al-'Aț̣ās, H. H., 2012). Manakala para Habaib yang membangunkan pesantren atau jamaah ta'lim di Palembang, Jawa Barat, Jawa Tengah dan Jawa Timur, Indonesia juga menjadikan Ratib al-Attas sebagai amalan benteng kerohanian (Al-Habshī, '., 1999; Al-Habshī, H. H., 2013). Begitu halnya yang berlaku di Brunei Darul Salam aplikasi amalan berjamaah ini telah menjadi modul kerohanian di seluruh Sekolah Agama Kerajaan dan masjid yang diasaskan oleh bekas Mufti Ismail Umar Abdul Aziz anak kelahiran Madrasah al-Attas, Johor Bahru, Johor (Mohamed \& Ibrahim, 2012).

Ratib adalah susunan zikir yang ringkas dan al-Attas bermakna bersin, kerana pengasasnya iaitu Habib Umar bersin semasa dalam kandungan ibunya (Al- 'Atțās, H. A. H., t.t; Azra, 2008) Zikrullah adalah Sultan al-Qurbi (method utama) mendekatkan diri kepada Allah S.W.T, merupakan dasar ilmu Ihsan bagi mencapai reda Allah S.W.T. (Muhammad, 2013). Pendekatan berzikir secara berjamaah di masjid, surau, madrasah, rumah kediaman adalah method yang telah lama berkembang dalam masyarakat Islam di Nusantara. Perhimpunan membaca al-Quran terutama Yasin dan tahlil, majlis khatam al-Quran, membaca maulid dan selawat atas Nabi SAW adalah amalan yang sangat baik dan memberi impak yang besar dalam (Al-Muarī, 2015; Mohd. Noor, 2011) menyatukan umat Islam dalam sesuatu komuniti (Mohd. Noor, 2011). Termasuk aplikasi membaca ratib al-Attas, al-Haddad atau apa-apa jenis ratib dalam Tarekat Alawiyah (Al-Attas, Habib Muhammad, 2102). Zikir adalah makanan bagi hati yang sihat dan ubat penawar bagi hati yang sakit (AlHabshī, 2007).

\subsection{DOKTRIN RĀTIB AL-ATTTĀS}

Berkata al-Imam al-Ghazali r.a: "Selepas daripada membaca al-Quran tiada ibadat yang dilakukan oleh lidah terlebih afdhal daripada zikrullah Ta'ala (Syeikh Abdul Samad al-Palembani, 2002). Manakala menurut al-Imam Jalaluddin al-Suyuti (2010) al-Mujahid berkata : "Tidak menjadi seorang hamba yang digelar banyak berzikir kepada Allah sehingga dia berzikir dalam keadaan berdiri, duduk dan berbaring".

Aplikasi amalan ini yang kebiasaannya diketuai oleh pembimbing yang berkelayakan dengan mendapat ijazah guru untuk membimbing para jamaah. Pembimbing juga akan memberikan bimbingan melalui tazkirah ringkas dan membaca hajat bagi tujuan perhimpunan tersebut, kemudian akan memulakan dengan membaca al-Fatihah secara beramai-ramai sebagai mengambil keberkatan untuk membuka majlis (Al-'Aț̣ās, H. Hasan 1996; Al-'Aț̣ās, S. M. N., 1999). Setelah itu, naqib membaca al-Hasyr, 59:21-24. Bacaan ini ditambah oleh Habib Ali bin Hasan al-Attas (Al- 'Atțās, H. A. H., 2007). 
Seterusnya 17 zikir ini dibaca secara berturutan dengan zikir pertama adalah ta'awuz (memohon perlindungan) dibaca sebanyak tiga kali. Ini bertepatan dengan beberapa hadis dalam riwayat (Al-Tirmidhi, 1998: 242; Abu Dawud, 2009: 775; Ahmad, 2001: 11473, 20306; AlDarimi, 2000: 1275). Lafaz bacaan tersebut adalah seperti berikut:

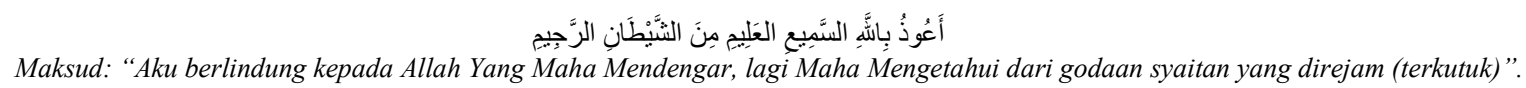

(Al-Tirmidhi, Abu Dawud, dan Ahmad)

Bacaan kedua daripada zikir tersebut juga adalah ta'awuz (memohon perlindungan), juga dibaca sebanyak tiga kali bersumberkan hadis dalam riwayat (Muslim, 2001: 2708, 2709; Al-Bukhari, 1994: 3371; Ibn Majah, 2009: 3518; Daud, 2001: 3898; Al-Tirmidhi, 1998: 3437) : Lafaz bacaan tersebut adalah seperti berikut:

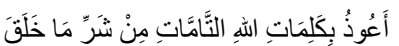

$$
\begin{aligned}
& \text { Maksud: "Aku berlindung dengan kalimah Allah yang sempurna (al-Quran) dari seluruh kejahatan mahluk-Nya". }
\end{aligned}
$$

Zikir ketiga termasuk bacaan basmalah yang dibaca sebanyak tiga kali yang bersumberkan beberapa hadis dalam riwayat (AlTirmidhi, 1998: 3388; Abu Dawud, 2009: 5088; Al-Nasa'i, 2001: 10106; Ibn Majah, 2009: 3869; Ahmad, 2001: 446): Lafaz bacaan tersebut adalah seperti berikut:

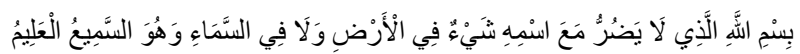

$$
\begin{aligned}
& \text { Maksud: "Dengan nama Allah, Tiada yang memudaratkan sesuatu di langit dan dibumi, Allah Maha Mendengar lagi Maha Mengetahui". }
\end{aligned}
$$

Zikir keempat adalah gabungan bacaan basmalah dan hauqalah yang diulang sebanyak sepuluh kali. Amalan ini adalah bersumberkan hadis dalam riwayat (Ibn al-Sunni, 1987: 1/298; Ibn Majah, 2009: 3878; Daud, 2001: 832; Al-Tirmidhi, 1998: 3570; Al-Bukhari, 1994: 3968) dan banyak diamalkan oleh para ulama yang besar (Al-Tabrani, 1993; Al-Sarraj, M. I., 2004; Ibn Bushran, 1997) tatkala memulakan sesuatu pekerjaan. Namun penyusun berijtihad untuk mengabungkan bacaan lafaz basmalah diawal hauqalah. Perkataan hauqalah adalah khazanah syurga Allah. Lafaz bacaan tersebut adalah seperti berikut:

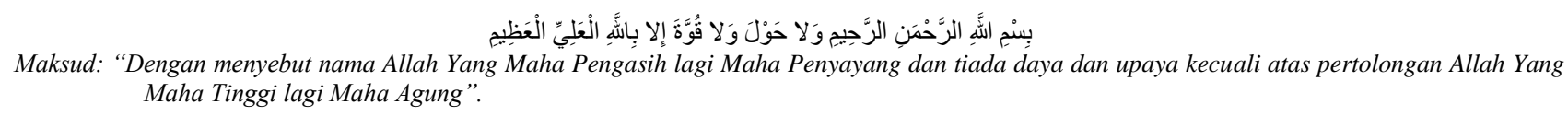

Zikir kelima dengan bacaan zikir yang diulang sebanyak 3 kali. Amalan ini adalah bersumberkan daripada hadis yang banyak dalam riwayat (Al-Bukhari, 1994: 7, 2941; Muslim, 2001: 400; Al-Tirmidhi, 1998: 245) iaitu kalimah permulaan surat Rasulullah s.a.w kepada raja Rom (Harqal), permulaan bacaan al-Quran dan solat sebelum al-Fatihah dalam mazhab Shafie. Lafaz bacaan tersebut adalah seperti berikut:

$$
\text { Maksud: “Dengan nama Allah Yang Maha Pemurah lagi Maha Mengetahui". }
$$

Zikir keenam dengan bacaan zikir yang diulang sebanyak 3 kali. Amalan ini adalah merupakan doa yang dibaca secara ijtihad penyusun memulakan dengan menyebut nama Allah sebagaimana firman Allah S.W.T dalam al- 'Alaq, 96: 1. Adapun sumber hadis dalam riwayat (al-Bukhari, 1994: 5991). Perintah dan arahan Allah menyebut namaNya yang A'zam (Maha Agung). Lafaz bacaan tersebut adalah seperti berikut:

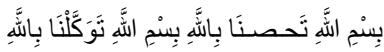

$$
\begin{aligned}
& \text { Maksud: "Dengan menyebut nama Allah kami berlindung kepada Allah, dengan menyebut nama Allah kami bertawakal kepada Allah S.W.T". }
\end{aligned}
$$

Zikir ketujuh dengan bacaan zikir yang diulang sebanyak 3 kali. Amalan ini bukan bersumberkan al-Quran dan hadis tetapi merupakan doa yang dibaca secara ijtihad penyusun yang tidak bertentangan dengan keduanya kerana memulakan dengan menyebut nama Allah sebagaimana firman Allah S.W.T dalam al- 'Alaq, 96: 1. Perintah dan arahan Allah menyebut namaNya yang A'zam (Maha Agung). Lafaz bacaan tersebut adalah seperti berikut:

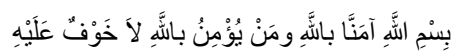

$$
\begin{aligned}
& \text { Maksud: "Dengan menyebut nama Allah kami beriman dan sesiapa yang beriman dengan Allah pasti tiada ketakutan baginya" }
\end{aligned}
$$

Zikir kelapan adalah termasuk bacaan tasbih dengan bacaan zikir yang diulang sebanyak 3 kali. Amalan ini bersumberkan al-Quran dan hadis namun bacaan ini adalah merupakan ijtihad penyusun yang tidak bertentangan dengan keduanya. Lafaz bacaan tersebut adalah seperti berikut:

$$
\text { Maksud: "Maha Suci Allah, Maha Mulia Allah Maha Suci Allah Maha Agung Allah". }
$$

Zikir kesembilan adalah bacaan tasbih dengan bacaan yang diulang sebanyak 3 kali. Amalan ini adalah bersumberkan hadis dalam riwayat (Al-Bukhari, 1994: 7563, 6682; Muslim, 2001: 2694) iaitu kalimah yang ringan pada sebutan, berat pada timbangan dan kalimah kecintaan Allah S.W.T. Lafaz bacaan tersebut adalah seperti berikut: 


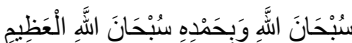 \\ Maksud: "Maha Suci Allah dan Segala Puji bagiNya, Maha Suci Allah Yang Maha Agung}

Zikir kesepuluh dengan bacaan tasbih, tahmid, tahlil dan takbir yang diulang sebanyak 4 kali. Amalan ini juga disebut sebagai kalimah al-Baqiayah al-Salihah sebagaimana Firman Allah dalam al-Kahfi, 18: 46, Mariam, 19: 76, juga sebaik-baik kalimah yang empat, menurut Imam Mujahid sebagai kalimah al-Takwa bersumberkan kepada hadis dalam riwayat (Al-Bukhari, 1994). Lafaz bacaan tersebut adalah seperti berikut:

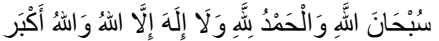

$$
\begin{aligned}
& \text { Maksud: "Maha Suci Allah dan Segala Puji bagi Allah dan tiada Tuhan yang patut disembah selain Allah dan Allah Maha Besar". }
\end{aligned}
$$

Zikir kesebelas adalah doa menyeru tiga nama Asmaullah al-Husna (Allah yang Maha Mulia) dengan bacaan sebanyak 3 kali. Amalan ini adalah merupakan ijtihad penyusun. Bacaan ini bertepatan dengan ayat al-Quran dalam al-A'raf, 7: 108, al-Isra', 15: 110 yang mengarahkan menyebut Asmaullah al-Husna iaitu Ya Latif, Ya Alim dan Ya Khabir sebagai perintah Allah S.W.T agar menyeru namanamaNya Yang Maha Mulia dalam berdoa bagi memohon sesuatu hajat permintaan. Doa ini juga dikatakan sebagai doa al-Lutf bagi Saidina Khaidir (Al- 'Atțās, H. A. H., 2007; Al-Ghazali, 2011) . Lafaz bacaan tersebut adalah seperti berikut:

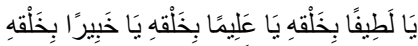

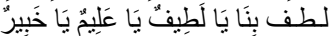

Maksud: "Wahai Zat Maha Belas kasih pada makhlukNya. Wahai Zat yang Maha Mengetahui keadaan mahlukNya. Wahai Zat Yang Maha Memerhatikan mahlukNya, kasihanilah kami Wahai Zat Yang Maha Belas Kasih, Yang Maha Mengetahui, Yang Maha Memperhatikan".

Zikir keduabelas dengan bacaan sebanyak 3 kali. Amalan ini adalah merupakan ijtihad penyusun sendiri namun sebutan Asmaullah al-Husna iaitu Ya Lațif sebagai seruan bersumberkan kepada ayat al-Quran dalam al-Shura, 42: 19, al-Mulk, 67: 14, al-An'aam, 6: 103, Yusof, 12: 100. Lafaz bacaan tersebut adalah seperti berikut:

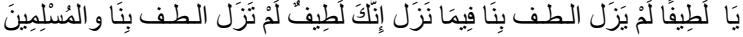

Maksud: "Wahai Zat Yang Maha Belas KasihNya tiada terbatas, kasihanilah kami dalam segala hal yang telah Kamu tentukan, sesungguhnya Kamu Yang Maha Lemah Lembut yang tiada henti. Oleh itu Kasihanilah kami dan semua kaum muslimin".
}

Zikir ketigabelas dengan bacaan sebanyak 40-100 kali. Amalan ini adalah bersumberkan kepada hadis dalam riwayat (Al-Bukhari, 1994: 8, 44, 53, 128; Muslim, 2001: 32, 33, 34, 36, 37; Daud, 2001: 169; Al-Tirmidhi, 1998: 976). Lafaz bacaan tersebut adalah seperti berikut:

$$
\begin{aligned}
& \text { لاَ إلَّهَ إِلَّا اللَّهُ } \\
& \text { Maksud: "Tiada Tuhan melainkan Allah". }
\end{aligned}
$$

Zikir keempatbelas dengan bacaan sebanyak 7 kali. Amalan ini adalah bersumberkan kepada hadis dalam riwayat (Al-Bukhari, 1994: 4563; Al-Tirmidhi, 1998: 2431; Muslim, 2001: 2272). Lafaz bacaan tersebut adalah seperti berikut:

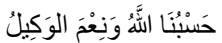

$$
\begin{aligned}
& \text { Maksud: "Cukuplah untuk (menolong) kami, dan ia sebaik-baik pengurus (yang terserah kepadanya Segala urusan kami)" . }
\end{aligned}
$$

Zikir kelimabelas dengan bacaan sebanyak 11 kali. Amalan ini adalah bersumberkan kepada Firman Allah S.W.T dalam al-Ahzab, 21: 56 menepati arahan, perbuatan Allah, para Malaikat serta hambaNya yang saleh, manakala bertepatan dengan amalan berselawat dalam solat lima waktu, juga menjadi rukun khutbah jumaat sebagaimana hadis dalam riwayat (Muslim, 2001: 405; Al-Bukhari, 1994: 3370, 4797; Daud, 2001: 976; Al-Tirmidhi, 1998: 483). Lafaz bacaan tersebut adalah seperti berikut:

$$
\text { Maknanya "Ya Allah selawat dan salam sejahtera ke atas Muhammad". }
$$

Zikir keenambelas dengan bacaan sebanyak 11 kali. Amalan ini adalah bersumberkan kepada firman Allah dalam Ali 'Imran, 3:135, al-Nisa, 5: 64, 110, 106, al-Anfal, 8: 33, Hud, 12: 52, 61, 90, al-Tahrim, 28: 8, merupakan perintah Allah S.W.T kepada hamba-hambaNya, begitu juga bertepatan dengan budaya istighfar Rasulullah s.a.w pada setiap hari melalui hadis dalam riwayat (Muslim, 2001: 591; AlBukhari, 1994: 5832, 6307; Daud, 2001: 1517; Al-Tirmidhi, 1998: 2070; Ibn Majah, 2009: 1637) . Lafaz bacaan tersebut adalah seperti berikut:

$$
\text { Maksud: “Aku memohon keampunan kepada Allah" }
$$

Kemudian diikuti dengan bacaan (نَائبُونَ إِلَىى الَّهِ $)$ sebanyak 3 kali.

Zikir ketujuhbelas dengan bacaan sebanyak 11 kali. Amalan ini adalah bersumberkan daripada firman Allah S.W.T dalam $a l-A h z a b$ 33: 41-42. Manakala menurut sumber hadis dalam riwayat Muslim 2001: 131. Namun begitu, zikir ini merupakan doa yang telah diijtihadkan penyusun bagi memohon kehidupan yang baik dunia akhirat yang tidak bertentangan dengan al-Quran dan hadis (Syed Omar, 2010; Mamat, 2010; Al-Qušairī, 2011). Lafaz bacaan tersebut adalah seperti berikut: 


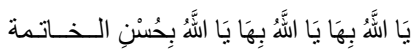

$$
\begin{aligned}
& \text { Maksud: "Ya Allah dengannya Ya Allah dengannya kesudahan yang baik (khusnul Khotimah atau Husnu Ma'ab)". }
\end{aligned}
$$

Kemudian disambung dengan bacaan terakhir dalam al-Baqarah, 285-286 (Sebagaimana dalam al-Hasyr 59: 21-24 pada awal bacaan ratib yang merupakan bacaan tambahan diasaskan oleh Habib Ali bin Hasan al-Attas, Sahib al-Mashad). Maksud ayat: "(Kami pohonkan) keampunanMu Wahai Tuhan kami, dan kepadamu jualah tempat kembali". Allah tidak memberati seseorang melainkan apa yang terdaya olehnya. ia mendapat pahala kebaikan yang diusahakannya, dan ia juga menanggung dosa kejahatan yang diusahakannya. (Mereka berdoa dengan berkata): "Wahai Tuhan kami! janganlah Kamu mengirakan kami salah jika kami lupa atau kami tersalah. Wahai Tuhan kami! janganlah Kamu bebankan kepada kami bebanan yang berat sebagaimana yang telah kamu bebankan kepada orang-orang yang terdahulu daripada kami. Wahai Tuhan kami! janganlah Kamu pikulkan kepada kami apa yang kami tidak terdaya memikulnya. dan maafkanlah kesalahan kami, serta ampunkanlah dosa kami, dan berilah rahmat kepada kami. Kamulah Penolong kami, oleh itu, tolonglah kami untuk mencapai kemenangan terhadap kaum-kaum yang kafir". (Al-Baqarah, 2: 285-286).

Berdasarkan kepada 17 zikir yang telah disebut di atas, maka boleh dikatogerikan 17 itu kepada 9 zikir utama iaitu 2 ta'awuz, 5 basmalah, 3 tasbih, 2 Ya Latif, tahlil, hasbalah, selawat, istighfar dan mohon doa husn al-khatimah. Bilangan kekerapan bacaan adalah 12 zikir dibaca sebanyak 3 kali, 4 kali bacaan pada 1 zikir, 7 kali bacaan hanya pada 1 zikir, 10 kali bacaan hanya pada 1 zikir, 11 kali bacaan pada 2 zikir dan yang paling banyak adalah 40-100 kali pada bacaan tahlil. Menurut Habib Hasan bahawa bilangan ini adalah ibarat mata kunci yang membuka segala pintu kesulitan dalam kehidupan bertepatan dengan namanya Aziz al-Manal Wa Fath Bab al-Wisal (Sesuatu yang sukar dicari bagi membuka pintu yang menyampaikan) (Al- Atțās, H. Hasan, 1997). Manakala terdapat 7 lafaz zikir yang diletakkan dalam ratib ini sebagai satu ijtihad bersumberkan al-Quran dan hadis serta amalan para kekasih Allah S.W.T. Oleh itu, ratib Habib Umar bin Abdul Rahman al-Attas ini sama sekali tidak terkeluar dari landasan syariat sebenar.

Setelah itu pembimbing akan membaca lima kali bacaan Fatihah sebagaimana dalam al-Hijr 14:87 dan dalam riwayat al-Tirmidhi 1998: 2800 yang ditujukan kepada Baginda Rasulullah s.a.w, Para Wali khususnya Saidina al-Muhajir Ilallah Ahmad bin Isa, keturunan Rasulullah pertama berhijrah dari Basrah ke Hadramaut, Yaman, Saidina al-Faqih Muqaddam, pengasas tarekat Alawiyah, Habib Umar bin Abdul Rahman al-Attas, Sahib al-Ratib, anak murid beliau yang setia berkhidmat iaitu Sheikh Ali bin Abdullah Baras, para guru-guru, ibubapa, seluruh muslim dan muslimat, yang terakhir atas harapan agar segala hajat yang dipohon diperkenankan Allah S.W.T. yang barakah ini disebut dalam al-Hijr, 14: 87 iaitu tujuh ayat pujian yang diulang sebagai tanda mengagungkan Allah S.W.T. Seterusnya yang terakhir adalah bacaan doa yang disusun oleh Habib Abdullah bin Alwi al-Haddad. Doa lengkap memohon kesejahteraan dan keselamatan dunia akhirat (wellness) (Al-Attas, Muhsin, 1997; Al- 'Aț̣ās, S. M. N. A., 2007)

\subsection{SUMBER DOKTRIN RĀTIB AL-ATTĀS}

Terdapat banyak dalil mengenai perintah zikir dalam al-Quran antaranya: Ingat pada Allah, maka Allah pasti ingat mereka dalam alBaqarah,1:152. Alat mendepani masa akan datang dengan merujuk (saat senang dan susah) kepada Maha Pencipta dalam alBaqarah,1:156. Doa mendekatkan kepada Allah S.W.T serta dimakbulkan segala permintaan dalam al-Baqarah, 1:186. Ubat dan kapsul segala penyakit zahir batin dalam Ali Imran, 3:134. Alat membentuk dan membina pemikiran positif dan kaedah menyelamatkan diri dari sambaran api neraka. Seterusnya mengingati Allah S.W.T (solat, puasa, zakat, haji, membaca al-Quran, dan lain-lain) dalam keadaan berdiri, duduk atau berbaring kemudian membaca doa memohon keampunan dan diakhiri kehidupan bersama insan bijaksana (abrar) di sisi Allah S.W.T. dalam Ali Imran,3:191-194. Saranan mengingati Tuhan dalam keadaan tunduk dan senyap dalam al-A'raf, 7:205. Berzikir sebagai satu cara menjadikan hati tenang dalam $a l-R a$ 'du, 13: 28. Modul dan kaedah mentaati dan melaksanakan perintah Allah S.W.T supaya manusia sentiasa ingat kepadaNya. (Al-Qušairī, 2011; Al-Sarraj, A. N., 2002; Al-Šaukan̄̄, 1988)

Mengingati Allah S.W.T tanda keimanan samada lelaki dan perempuan, sendirian atau berjamaah, dengan ingatan yang sebanyakbanyaknya pada setiap waktu pagi dan petang dalam al-Ahzab, 33:41-42. Insan yang berzikir lelaki dan perempuan akan beroleh pengampunan dan ganjaran pahala yang besar di sisi Allah dalam al-Ahzab, 33:35. Kedudukan zikir adalah tinggi di sisi Allah kerana ia adalah pekerjaan yang utama dalam al-Ankabut, 29:45. Mencapai cahaya Ilahiyah melalui zikrullah dalam al-Nur, 24:35-37. Modal dan keuntungan (al-baqiyat al-șalehah) untuk menghadap dan melihat Allah di Hari Kiamat kelak dalam as-Syu'ara, 26: 88-89 dan al-Kahfi, 18:46. Alat pembersihan jiwa (tazkiyah al-nafs) dalam al-Shams, 91:9-10.

Keutamaan zikrullah dan kelebihan menganjurkan majlis zikrullah secara beramai-ramai juga bersumberkan kepada hadis antaranya perumpamaan insan yang berzikir dengan mereka yang tidak berzikir ibarat insan yang hidup dan mati dalam riwayat al-Bukhari, 1993: 832, 6090, 6091, 6854, 6856 manakala dalam riwayat Muslim, 2001: 558, 1299, 4834, 4850, 4851, 4854, 4867, 4927, 4937, 4938, 5352. Berdasarkan kepada dua sumber utama dalam ASWAJA mengharuskan aplikasi zikrullah dalam mana-mana tarekat yang muktabar (AlPalembanī, 2002; Al-Makkī, 2010; Al-Jailānī, 2011).

\subsection{KAEDAH APLIKASI RĀTIB AL-ÁTTĀS}

Rātib al-Attās adalah amalan yang ringkas dan mudah. Boleh diamalkan secara bersendirian atau berjamaah pada bila-bila masa khususnya pada waktu pagi, petang atau malam di mana-mana lokasi yang sesuai terutama masjid dan surau, boleh juga diadakan di rumah kediaman, permis perniagaan, balai raya, dewan dan sebagainya. Amalan ini boleh diaplikasi dalam apa jua keadaan samada duduk, berdiri atau berbaring sebagaimana Ali-Imran, 3:191. Amalan ini juga tidak terikat dengan ijazah guru, namun hadir dalam majlis Rātib al-'Attās secara langsung telah mendapat ijazah guru dan untuk mengambil amalan ini dari para Habaib yang berkelayakan tidak memerlukan suatu baiah tertentu. (Al-'Aț̣ās, H. Hasan 1996; Al- 'Aț̣ās, H. Hasan, 1997).

Adapun memiliki seorang guru yang mursyid adalah tuntutan kebanyakan amalan tasawuf dan tarekat. Guru mursyid sebagai petunjuk jalan yang lurus (Al-Šhuhrawardī, 2009; Al-Kurdī, 2004; Bin Šheikh Abu Bakar, 2014). Dalam aplikasi amalan ini yang dilakukan secara berjamaah di mana-mana lokasi perlu kepada pimpinan seorang guru kerana ada di kalangan pengikut yang kurang berkebolehan membaca zikir-zikir dan doa tersebut dengan baik disamping mereka yakin barakah guru mursyid dan lokasi zikir terutama 
rumah Allah S.W.T. sebagaimana yang disebutkan dalam surah Qaf, 50:37. Selain itu, seseorang murid yang memiliki guru pembimbing mempunyai hati yang bersih, ikhlas, ihsan, dan kemahiran mendengar serta menjadi saksi kepada zikir yang dibaca (Al-Merbawī, 2001; Mamat, 2010).

\subsection{PENUTUP}

Dapatan kajian ini menunjukkan bahawa doktrin zikir 17 yang diasaskan oleh Sahib al-Ratib iaitu Habib Umar bin Abdul Rahman al-Attas adalah doktrin zikir yang diwarisi aplikasinya di seluruh dunia sejak turun temurun terutamanya di Hadralmaut, Yaman dan nusantara khususnya di negeri Johor Darul Takzim. Zikir ini adalah pusaka dan warisan wali Allah yang bertaraf Qutub serta bertepatan menurut perspektif al-Quran dan Hadis seperti yang telah dibincangkan. Ianya menjadikan sesuatu amalan zikir yang lebih diterima dalam kalangan ilmuwan dan juga masyarakat awam. Hal ini kerana sekiranya amalan-amalan zikir yang diamalkan tiada dalil yang sahih menyebabkan kurang mendapat sambutan masyarakat untuk diamalkan. Oleh yang demikian aplikasi majlis Ratib al-Attas bukanlah satu bidaah yang sesat dan mengelirukan, namun ia menjadi pilihan terhadap zikir yang bersesuaian untuk diamalkan di semua peringkat masjid, surau, pusat pendidikan menengah dan rendah, termasuk di rumah kediaman serta lokasi dan waktu yang bersesuaian bagi mencapai objektif hajat dunia dan akhirat serta mencapai keredhaan Allah SWT.

\section{Rujukan}

Abdul Rahman, Subki, Myiddin, Rifqi. (2011). Amalan Sunnah Selepas Solat \& Kelebihannya. Telaga Biru Sdn. Bhd., Kuala Lumpur.

Abu Dawud, Sulaiman. (2009). Sunan Abi Dawud . al-Arna'ut Shu'aib \& Muhammad Kamil Qurrah Balali. 1-7. Dar al-Risalah al- 'Alamiyyah, Beirut.

Ahmad, Hambal. (2001). Musnad al-Imam Ahmad bin Hambal. Shu'ay al-Arna'ut \& 'Adil Murshid. Mu'assah al-Risalah, Al-Qahirah.

Al- 'Aț̣̄ās, Al-Habib Syed Muhammad. (2014). Amalan Ratib Al-'Aț̣ās di Huraidah, Hadramaut, Yaman. In Mohd. Azman Mohsin (Ed.), Doktor Falsafah, 1-2. UTM, Skudai, Fakulti Tamadun Islam, Johor.

Al-'Aț̣ās, H. Abdullah Alwi Hassan. (1968). Sabīl al-Muhtadīn F̄̄ Zikrī Adiyah al-Ashab al-Yamīn. Kaherah.

Al-'Attās, H. Ali Hasan. (2007). Al-Oirtās, Šharah Rātib 'Atțās. t.c: t.p.

Al-'Aț̣ās, H. Ali Hasan (t.t). Majmuk Mualafāt. Maktabah Ma'ruf, Jakarta, Indonesia.

Al-'Ațẫa, H. Hasan (1996). Umar bin Abd. Rahman, Kisah Dan Sejarah al-Qutub al-Anfas al-Habib Umar bin Abd Rahman Al-Attas. Masjid Ba'Alawi, Singapura.

Al-'Attās, H. Hasan (2010). Kelebihan Ratib. Masjid Ba'Alawi, Singapura.

Al- 'Aț̣āas, H. Hasan (2012). The Spread Of Islam And The Role Of The Sufis. Masjid Ba'Alawi, Singapura.

Al-'Attās, H. Hasan (1997). Kelebihan Ratib, huraian Ratib al-Habib Umar bin Abdul Rahman 'Attās. Masjid Ba'Alawi, Singapura.

Al-'Aț̣ās, H. Hasan Abdullah (t.th.). Tazkīrun Nās. Dar Ihya al Kutub al-Arabiyah Isa al-Babi al-Halabi wa Syarikat, Kaherah, Mesir

Al-'Aț̣ās, H. Muhammad (2012). 'Aziz al-Manāl Wa Fathu Bāb al-Wisāl Pembuka Jalan Mendekatkan diri Kepada Allah. Percetakan Nasional Bhd., Kuching, Sarawak.

Al-'Aț̣ās, S. Abdullah (t.th.). Al-Ilmu al-Nabrās Fī al-Tanbih Alā Manhaj al-Akyas T.P., T.T.P.

Al-'Aț̄ās, S. Muhammad Naqib (1999). The Rare Gift And The Key To Opening The Door Of Union. Masjid Ba'Alawi, Singapura.

Al-'Aț̣ās, S. Muhammad Naqib Ali. (1977). Islam: Faham Agama dan Asas Akhlak. Angkatan Belia Islam Malaysia (ABIM), Kuala Lumpur.

Al- Ațtāas, S. Muhammad Naqib Ali. (2007). The Rare Gift And The Key To Opening The Door Of Union. The Mosque BaAlawi, Singapore.

Al-'Atțās, S. Mustafa. (2008). Al-Tarīkah 'Attāsīyah al- 'Alawīyah. t.c, t.p.

Al-'Aț̣ās, Syed Ali. (2013). Amalan dan Doktrin Ratib Al- Aț̣ās di Masjid Habib Hasan, Johor Bahru. In Mohd. Azman Mohsin (Ed.), Doktor Falsafah, 1-2. Fakulti Tamadun Islam, UTM Skudai, Johor.

Al-Bukhari, Abu Abdullah Muhammad. (1994). Sahih al-Bukhari ‘'Abd al-Aziz 'Abdullah, 1-5. Dar al-Fikr, Beirut.

Al-Darimi, Abu Muhammad Abdullah. (2000). Sunan al-Darimi. Hussain Salim Asad Al-Darani, 1-4. Dar al-Mugni li al-Nasr wa al-Tawzi`,Al-Mamlakat al'Arabiyyah al-Sa'udiyyah.

Al-Ghazali, Al-Imam Muhammad. (2011). Ihya' 'Ulūm al-Dīn, 1-8. Victory Ajensi, Kuala Lumpur.

Al-Habshī, 'Aīdrūs (1999). 'Akdu al-Yawākīt al-Jauharīyah Wā Sumtu al-Ain al-Zahabīyah. Maktabah Pustaka Nasional, Singapura.

Al-Habshī, H. Ahmad (2007). Šharah al- 'Ainiyah. Dar al-Minhaj, Surabaya, Indonesia.

Al-Ḥabshī, Habib Hamid. (2013). Amalan Ratib Al-'Ațtās di Pasentren Palembang, Indonesia. In Mohd. Azman Mohsin (Ed.), Doktor Falsafah, 1-2. Fakulti Tamadun Islam, UTM, Skudai, Johor.

Al-Haddād, al-Ḥabīb Syed Abu Bakar. (2013). Amalan Ratib Al- Ațtās dan Asmaulllah al-Husna di MHH Johor Bahru. In Mohd. Azman Mohsin (Ed.), Doktor Falsafah, 1-10. Fakulti Tamadun Islam, UTM, Skudai, Johor.

Al-Haddād, H. Alwi (2005). Šhārah Rātib Al-Haddād. Maqam al-Imam al-Haddad, Tarim, Hadramaut, Yaman.

Al-Ḧaddād, H. Alwi Tahir. (1991 ). 'Ukūd al-Mās Bī Manakib al-Imām al-Habib Ahmad bin Hasan bin Abdullah Al-'Atțās. Cetakan Kerjaya, Singapura.

Al-Jailānī, Šheikh Abdul Qadir (2011). Al-Ğhyuniah li Tālibi Tārik al- Hak ‘Azawajallā. Darul al-Taufiqiah Li Turath, Kaherah, Mesir.

Al-Jufri, Abdul Latif, Ibnu Mohsin al-Muari. (2013). Pendekatan Dakwah Wali 9. Majlis Agama Islam Johor, Johor Bahru.

Al-Khalidī, Sidek, Jahid (1994). Shaikh dalam Ilmu Tariqah. Tesis Doktor Falsafah, Universiti Malaya, Kuala Lumpur.

Al-Kurdī, Muhammad Amin. (2004). Tanwīr al-Qulūb Fi Muamalah Allam al-Ghuyub. Dar al-Fikr, Beirut, Lubnan.

Al-Makkī, Šheikh Abi Talib (2010). Qūt al-Qulūb Fì Muamalah al-Mahbūb. Darul Sodir, Beirut.

Al-Merbawī, Mohamad, Abdul Manam (2001). Tarekat Naqsabandiah Dan Sejarah Kemasukkannya Ke Malaysia. Tesis Doktor Falsafah, Kuala Lumpur.

Al-Muarī, Ibnu Mohsin (2009). Ratib Al- 'Ațtās dan Asmaul Husna : Amalan Menuju Kebahagian (Zikir Pagi Dan Solat Sunat Dhuha). Johor Bahru, Johor Darul Ta'zim.

Al-Muarī, Mohsin Mohd. Azman (2015). Rātib al- 'Atțās dan Asmaullah al-Husnā, Jalan Petunjuk Dan Kebijaksanaan. Rimbunan Ilmu Sdn. Bhd., Kuala Lumpur.

Al-Muarī, Mohsin, Mohd.Azman (2006). Ratib al- 'Attās dan Asmaul Husna : Menuju Husnul Khatimah. Al Hidayah Publisher, Kuala Lumpur.

Al-Nasa'i, Ahmad. (2001). Al-Sunan al-Kubra .Hasan 'Abd al-Man'am Shilbi, 1-10. Mu'assasah al-Risalah, Beirut.

Al-Palembanī, Šheikh Abdul Samad (2002). Sairu al-Salikin : Jalan Para Salik untuk mengabdikan diri kepada Tuhan Rabbul Alamin. 381. Tahqiq Syed Ahmad Semait. Pustaka Nasional, Singapura.

Al-Qušairī, Imam Abdul Karim. (2011). Risalah al-Qušaīriah. Jakarta, Dar al-Kutub al-Islamiyah, Indonesia.

Al-Sarraj, Abu Nashr. (2002). al-Luma' Rujukan Lengkap Ilmu Tasawuf. Surabaya, Jawa Timur, Risalah Gusti, Indonesia.

Al-Sarraj, Muhammad Ishaq. (2004). Hadith al-Sarraj. Abu 'Abdullah Hussayn bin 'Aqashah bin Ramadan.Al-Faruq al-Hadithah li al-Tiba'ah wa al-Nasr, T.T.P.

Al-Šaukanī, Imam Muhammad bin Ali (1988). Tuhfah al-Zākirīn. Muasasah al-Kutub al-Thaqafiayah, Beirut, Lubnan.

Al-Šhuhrawardī, Umar (2009). 'Awārif al-Maārif. Dar al-Mukatam, Kaherah, Mesir.

Al-Šiblī, Muhammad. (1982). Al-Masrāa al-Rawī Fì Manāqib al-Sädah al-Kirām 'Aali Abi Alawī (t.c).

Al-Tabrani, Sulaiman Ahmad. (1993). Al-Dua' li al-Tabrani. Dar al-Kutub al-'Ilmiyyah, Beirut.

Al-Tirmidhi, Muhammad. (1998). Al-Jami' al-Kabir - Sunan al-Tarmidhi. Bashar 'Awad Ma'ruf. 1-6. Dar al-Girb al-Islami, Beirut. 
Al-Yafie, Abdullah (2003). Al-Irshad Wa al-Tațriz Fì Fadli Zikrullah Wa Tilāwah Kitāb al- 'Azīz. Darul Kutub al-Ilmiyah, Beirut, Lubnan. Azra, Azyumardi (2008). Ensiklopedi Tasawuf. Penerbit Angkasa Bandung, Bandung, Indonesia.

Bin Šheikh Abu Bakar, al-Habīb Umar Hafidz (2014). Taujihāt al-Nabiyah Li Marḍa al-Bariyah. Dar al-Faqir, Tarim, Hadramaut, Yaman.

Daud, Al-Imam Abu. (2001). Aunul Ma'bud šyārah sunan Abi Daud. Darul Hadis, Kaherah, Mesir.

Fauzi, Nurul Wahidah (2012). Ulama Arab Hadrami Dalam Pentadbiran Dan Pendidikan Islam Di Johor: Analisis Terhadap Sumbangan Syed Abdul Qadir bin Muhsin al-Attas dan Syed Alwi bin Tahir al-Haddad. Doktor Falsafah, Universiti Malaya, Kuala Lumpur.

Fauzi, Nurulwahidah, Ladjal, Tarek, Denisova, Tatiana A, Nor, Mohd Roslan Mohd, \& Zin, Aizan Ali Mat. (2013). Tareqat Alawiyah as an Islamic Ritual Within Hadhrami's Arab in Johor. Middle-East Journal of Scientific Research, 14(12), 1708-1715.

Ibn al-Sunni, Ahmad. (1987). 'Amal al-Yawm wa al-Laylah Suluk al-Nabi ma a Rabbihi 'Azz wa Jalla wa Mu 'asharatihi ma 'a al- 'Ibad. Damsyiq: Dar al-Fayha'.

Ibn Bushran, ‘Abd al-Malik Muhammad. (1997). Amali Ibn Bushran. Abu 'Abd al-Rahman 'Adil bin Yusuf al-'Azazi. Dar al-Watan, Al-Riyad.

Ibn Majah, Muhammad Yazid. (2009). Sunan Ibn Majah (Shu'ayb Al-Arna'ut, 'Adil Murshid, Muhammad Kamil Qurrah Balali \& 'Abd al-Latif Hirzullah. 1-5. Dar alRisalah al-'Alamiyyah, Beirut.

Mamat, Akila (2010). Amalan Ratib al-Haddad di Daerah Kuala Terengganu. Sarjana, Universiti Kebangsaan Malaysia, Bangi, Selangor.

Mohamed, Abdul Qadir, \& Ibrahim, Jaafar (2012). Amalan Ratib al- Aț̣ās di Brunei Darul Salam. In Mohd. Azman Mohsin (Ed.), Doktor Falsafah, 1-2. Fakulti Tamadun Islam, Skudai, Johor.

Mohd. Noor, Sulaiman Sakib (2011). Model Khidmat Nasihat Keluarga Islam Institusi Masjid. Doktor Falsafah, Universiti Teknologi Malaysia, Johor, Skudai, Johor Mokti, Kiyai Muhammad Muhtar. (2012). Sejarah Penyusunan Doa Kautsaran. Jombang, Jawa Timur, Al-Ikhwan 1, Indonesia.

Muhammad, Yusuf. (2013). Al-Mausūāt al-Yusūfiah Fi Bayān Adilah al-Sūfiah. Maktabah Tarim al-Hadithiah, Tarim, Hadramaut, Yaman.

Muslim, Abu al-Husayn. (2001). Sahih Muslim, 1-2. Al-Maktabah al-Asriyyah, Beirut.

Muslim, Abu al-Husayn. (t.th.). Sahih Muslim, 1-8. Dar al-Fikr, Beirut.

Napiah, Othman (2002). Al-Rabitah Dalam llmu Tasawuf. Tesis Doktor Falsafah, Universiti Malaya, Kuala Lumpur.

Syed Omar, Syed Hadzrulattfi. (2010). Dhikr Ism al-Zat Dalam Tasawuf Dan Pengamalannya Dalam Tarekat Naqshabandiyah Khalidiyyah Di Malaysia. Doktor Falsafah, Universiti Malaya, Kuala Lumpur. 